\title{
Sleep habits and the relationship thereof with mental health indicators in childhood
}

\author{
Thaísa Gios, Tatiana P. Mecca, Juliana Akemi, Lucas E. Kataoka, and Rosane Lowenthal \\ Department of Mental Health, Santa Casa de Sao Paulo School of Medical Sciences (FCMSCSP)
}

Received: April 28 $8^{\text {th }}, 2020$.

Accepted: August $9^{\text {th }}, 2021$.

$$
\begin{gathered}
\text { Author Note } \\
\text { Thaísa Gios (D) https://orcid.org/00oo-0002-9408-3403 } \\
\text { Tatiana P. Mecca (D) https://orcid.org/0000-0002-2009-6228 } \\
\text { Juliana Akemi (D) https://orcid.org/0000-0003-4038-833X } \\
\text { Lucas E. Kataoka (D) https://orcid.org/00oo-0001-7117-3919 } \\
\text { Rosane Lowenthal (D) https://orcid.org/00oo-0002-6330-850X }
\end{gathered}
$$

Funding: Scholarship of Junior Scientific Initiation of the National Council for Scientific and Technological Development (CNPq) and Master's Program (FCMSCSP/FAVC).

Correspondence concerning this article should be addressed to Rosane Lowenthal, Departamento de Saúde Mental, Faculdade de Ciências Médicas da Santa Casa de São Paulo. Rua Dona Veridiana, 55, $3^{\circ}$ andar, São Paulo, SP, Brazil. CEP: 01238-010. E-mail: rosane.lowenthal@gmail.com 


\begin{abstract}
This study investigated the relationship between sleep habits and mental health indicators in childhood reported by caregivers, in addition to seeking evidence of validity and reliability of the Children Sleep Habits Questionnaire (CSHQ), Brazilian version (CSHQ-BR). Sixty children participated, between 4 and 10 years old, from a public school in the central region of São Paulo, in 2019. The overall mean of the CSHQ-BR score was 49.08. There were no differences between sex in the CSHQ and the Strengths and Difficulties Questionnaire (SDQ) scores. Positive and significant correlations were observed between the CSHQ and the SDQ, specifically between difficulties, parasomnias, sleep-disordered breathing with emotional problems, and hyperactivity. Sleep problems explain $23 \%$ of the variance of the SDQ scores. The Cronbach's Alpha Coefficient was 0.75 , indicating adequate internal consistency. These findings point to evidence of the validity and accuracy of the CSHQ-BR. Sleep habits are associated with indicators of emotional and behavioral problems.
\end{abstract}

Keywords: sleep, mental health, childhood, internalizing problems, externalizing problems

\title{
HÁBITOS DE SONO E RELAÇÃO COM INDICADORES DE SAÚDE MENTAL NA INFÂNCIA
}

\section{Resumo}

Este estudo investigou a relação entre hábitos de sono e indicadores de saúde mental na infância relatados por cuidadores, além de buscar evidências de validade e precisão da adaptação para o Brasil do Children's Sleep Habits Questionnaire (CSHQ). Participaram 60 crianças, entre 4 e 10 anos, de uma escola pública da região central de São Paulo, em 2019. A média geral no CSHQ-BR foi 49,08. Não houve diferenças de sexo nos escores do CSHQ e do Strengths and Difficulties Questionnaire (SDQ). Houve correlações positivas e significativas entre o $\mathrm{CSHQ}$ e o SDQ, especificamente entre dificuldades, parassonias e distúrbios respiratórios do sono com problemas emocionais e hiperatividade. Hábitos de sono explicaram 23\% da variância no SDQ. O coeficiente alfa de Cronbach do CSHQ-BR foi 0,75, indicando consistência interna adequada. Esses achados apontam evidências de validade e precisão do CSHQ-BR. Hábitos de sono estão associados a indicadores de problemas emocionais e comportamentais.

Palavras-chave: sono, saúde mental, infância, problemas internalizantes, problemas externalizantes

\section{HÁBITOS DE SUEÑO Y RELACIÓN CON INDICADORES DE SALUD MENTAL EN LA INFANCIA}

\section{Resumen}

Se investigó la relación entre hábitos de sueño y indicadores de salud mental infantil reportados por cuidadores, además de buscar evidencia de validez y precisión de la adaptación del Cuestionario de Hábitos de Sueño Infantil (CSHQ) para Brasil. En 2019 participaron 60 niños de 4 a 10 años de una escuela pública de la región central de São Paulo. El promedio general en el CSHQ-BR fue 49,08. No hubo diferencias de género en las puntuaciones del CSHQ y del Cuestionario de Fortalezas y Dificultades (SDQ). 
Hubo correlaciones positivas y significativas entre CSHQ y SDQ, específicamente entre dificultades, parasomnias y trastornos respiratorios del sueño con problemas emocionales e hiperactividad. Hábitos de sueño explicaron 23\% de la variación en el SDQ. El coeficiente alfa de Cronbach de CSHQ-BR fue 0,75 , indicando una consistencia interna adecuada. Estos hallazgos apuntan evidencia de validez y precisión del CSHQ-BR. Hábitos de sueño están asociados con indicadores de problemas emocionales y de comportamiento.

Palabras clave: sueño, salud mental, infancia, problemas de internalización, problemas de externalización 
Sleep is a complex and fundamental phenomenon for healthy development. It interferes with behavior, memory consolidation, and other cognitive, metabolic, hormonal, and emotional regulation aspects. When inadequate, it is a risk factor for obesity, diabetes, heart disease, immunity, and mood disorders, interfering with the individual's physical and mental well-being, causing functional impairment and losses in interpersonal relationships (Barbisan, \& Bueno, 2019; Neves et al., 2017; Silva et al., 2014).

Sleep difficulties are common in childhood, affecting about $20-30 \%$ of children having typical development and $80 \%$ of children with neurodevelopmental disorders (Damiani et al., 2014; Moore et al., 2017). Anxiety and depression, attention deficit hyperactivity disorder (ADHD), and autism spectrum disorder (ASD) often occur in association with or as a comorbidity with insomnia (Nunes \& Bruni, 2015; Vaughn et al., 2015; Liu et al., 2014). It is estimated, for example, that $25 \%$ to $50 \%$ of children with ADHD have sleep disorders (Miano et al., 2012; Paavonen et al., 2009).

Studies from different countries show that the association between sleep disorders and emotional/behavioral problems in children appears to be universal (Nunes \& Bruni, 2015; Wu et al., 2016; Wang et al., 2020; Whalen et al., 2016). Aspects related to short-duration sleep or bedtime irregularities are associated with attention problems, aggressive behaviors, hyperactivity, and emotional symptoms (Wu et al., 2016; Wang et al., 2020; Whalen et al., 2016; Schlarb et al., 2016). Furthermore, children with sleep disorders have greater non-adaptive changes in the process of generating and regulating emotions, more difficulties in the relationships with their peers, and poorer readiness for learning with an impact on their school performance (Tso et al., 2016).

Research indicates that sleep disorders in children are significant predictors of later emotional and behavioral problems, such as anxiety, depression, somatic complaints, attention problems, poorly developed executive functions, and aggressive behaviors (Nelson et al., 2018; Whalen et al., 2016; Nunes \& Bruni, 2015; Owens \& Mindell, 2011).

The clinical presentations of sleep disorders are variable. During the first years, complaints of difficulty falling asleep and/or nocturnal awakenings are frequent. After this period, parasomnias (such as confusional arousals, sleepwalking, and night terrors) and sleep-disordered breathing (such as obstructive sleep apnea) are observed. From preschool age, disorders related to issues of inadequate sleep hygiene occur and, in adolescence, it is possible to observe disorders related to circadian issues or excessive movement during sleep (Nunes \& Bruni, 2015).

A recent study investigating sleep and mental health problems in preschool children in China and Japan showed an association between emotional and behavioral problems and sleep disorders. However, there was a difference in mental health and sleep aspects across countries. For instance, Chinese children with sleep difficulties have more relationship problems 
with their peers. In China, the most frequent sleep disorders are respiratory problems and daytime sleepiness, whereas, in Japan, those are sleep anxiety and nocturnal awakening (Wang et al., 2020). This indicates that cultural differences can have different impacts on the relationship between specific sleep characteristics and mental health indicators in childhood.

Early detection of sleep disorders and risk factors for psychiatric disorders is essential, as it provides for adequate management and, consequently, a favorable prognosis, thereby avoiding the chronicity of the diseases involved. The use of screening instruments, such as the Children's Sleep Habits Questionnaire (CSHQ) and the Strength and Difficulties Questionnaire (SDQ), can help in daily practice, since they are quick and easy to administer.

The CSHQ is a questionnaire on sleep habits developed by Owens et al. (2000), widely used in international studies on childhood sleep. The questionnaire's items and structure are based on common clinical presentations of the most prevalent diagnoses according to the International Classification of Sleep Disorders and assesses parents' perception of their children's sleep.

There are adaptations of this questionnaire for several languages, such as Chinese (Liu et al., 2003), Hebrew (Tzchishinsky et al., 2008), Dutch (Waumans et al., 2010), German (Schlarb et al., 2010), Spanish (Cruz et al., 2016), European Portuguese (Silva et al., 2014) and, for most of them, there are previous validity evidence studies. In Brazil, its translation, cross-cultural adaptation, and first psychometric studies using it have been carried out recently (Gios, 2020).

Regarding the screening of mental health problems in childhood, there is the SDQ, which consists of a total of 25 items divided into five subscales. The Brazilian version of the SDQ presents previous national validity evidence studies for screening mental health in childhood (Saur \& Loureiro, 2012; Silva et al., 2015). SDQ scores allow one to identify internalizing symptoms and externalizing behavior problems (Goodman, 1997).

Given the association between sleep disorders and behavioral problems in children, as well as the scarcity of national studies that use screening instruments consolidated in the literature, this study aimed to investigate the relationship of sleep patterns with mental health indicators in childhood as reported by their caregivers. Furthermore, the data obtained with this study will provide validity evidence based on the relationship with external variables pertaining to the adaptation of the CSHQ to Brazilian Portuguese. According to the literature review, the hypothesis is that correlations of low to moderate magnitude are observed between sleep problems and an increase in mental health problems in children, as reported by their caregivers.

\section{Method}

\section{Study design and general aspects}

This is a cross-sectional, observational, descriptive, correlational study. Data collection was carried out in 2019, during a parents' meeting at a public school in the central region 
of the city of São Paulo, Brazil. During the meeting, caregivers were invited to attend lectures on sleep and fill out the questionnaires with the help of a team composed of medicine and speech therapy students previously trained to administer the instruments.

\section{Participants}

The sample was selected by convenience. Sixty children participated in this study ( $53.3 \%$ boys), aged between 4 years old and 10 years and 11 months old $(M=7.66$ and $S D=1.36)$, all of whom were students from a public school in the city of São Paulo, Brazil. According to the Economic Classification Brazil criterion, by the Brazilian Association of Research Companies, the studied population's mean is within the socioeconomic status $C_{1}(M=25.78)$, with an estimated mean household income of BRL $\$ 3,085.48$ (ABEP, 2019). Of the total, $70 \%$ of the questionnaires were filled out by mothers, $13.3 \%$ by fathers, $10 \%$ by grandparents, and the remaining $6.7 \%$ did not respond.

\section{Inclusion and Exclusion Criteria}

The inclusion criteria for caregivers (parents and/or guardians) were that they needed to stay with the child for at least six nights a week. Children whose caregivers reported genetic syndromes, psychiatric disorders, or continuous use of psychotropic drugs were excluded from the study.

\section{Instruments}

- CSHQ: In this study, an abbreviated version of the CSHQ was used. It had already been translated and was undergoing the validity evidence process for Brazilian Portuguese (Gios, 2020). This questionnaire includes items related to key domains covering the main clinical sleep complaints in the pediatric age group. The 33 items are conceptually grouped into eight subscales, reflecting the following sleep domains: resistance to going to bed, sleep onset, sleep duration, sleep anxiety, nocturnal awakenings, parasomnias, sleep-disordered breathing, and daytime sleepiness. It is used to screen children between 4 and 10 years of age for sleep disorders. This age limit was defined with the aim of minimizing the possible effects of pubertal changes on sleep behavior. The frequency of sleep behaviors is rated on a three-point scale, namely: "usually" (occurs five to seven times a week), "sometimes" (occurs two to four times a week), or "rarely" (zero or once a week) (Owens et al., 2000). The BR- CSHQ is described in Appendix 1.

- $\quad$ Strengths and Difficulties Questionnaire (SDQ): An instrument used to screen for mental health problems in childhood. It comprises 25 items divided into five subscales: prosocial behavior problems, hyperactivity, emotional problems, con- 
duct problems, and relationship problems, with five items in each subscale. The responses can be: false (zero points); more or less true (one point); or true (two points); and each item is given a specific score. The exception occurs in the prosocial behavior subscale, in which the higher the score, the smaller the number of complaints. For each of the five SDQ subscales, the score can range from o to 10 , with the total difficulty score being generated by the sum of the results of all subscales, except for sociability, ranging from o to 40 points (Goodman, 1997).

- The Economic Classification Brazil Criterion, by the Brazilian Association of Research Companies (Critério de Classificação Econômica Brasil da Associação Brasileira de Empresas de Pesquisa; ABEP, 2019): It presents a classification of socioeconomic status by considering all the goods that are within a given household (irrespective of the form of purchase), level of education, and housing conditions. It stratifies a given population into seven socioeconomic statuses (SES).

\section{Procedures and Ethical Considerations}

The study was approved by the Ethics Committee at Irmandade da Santa Casa de Misericórdia de São Paulo. The assessment of sleep problems and the mental health screening were approved in two distinct individual projects (CAAE 99698918.1.0000.5479; CAAE 20689919.3.0000.5479). The person in charge of the institution where data collection took place, as well as those legally responsible for the children, signed a Voluntary Informed Consent Form (VICF), as recommended by Resolution n. 510/2016 of Brazil's National Health Council for research with human beings. Participants were informed about the procedures, confidentiality of the data to be collected, and anonymous disclosure of results.

\section{Data Analysis}

Data were analyzed using the software Statistical Package for Social Sciences (SPSS) - version 21.0. Descriptive statistics (mean and standard deviation) were employed in order to characterize the sample in terms of questionnaire scores. To verify the adequacy of data distribution and define the type of inferential analysis to be conducted, the Kolmogorov-Smirnov test was used, and the asymmetry and kurtosis values of the SDQ and CSHQ scores were described. Asymmetry values for the SDQ ranged around -1 and 1 , with the exception of prosocial behavior; while kurtosis values diverged from those which were expected. In the CSHQ, some of the subscale values are asymmetric and far from the expected values. Finally, the Kolmogorov-Smirnov test showed statistical significance $(p \leq 0.05)$ and, therefore, non-parametric analyses were conducted.

The scores of boys and girls in SDQ and CSHQ were compared using the Mann-Whitney test. A Spearman correlation analysis was performed between the SDQ and CSHQ scores 
and then, finally, also a linear regression analysis was performed considering sleep disorders as an independent variable and behavior problems as an outcome. The instrument's precision for this sample was obtained by an internal consistency analysis, more specifically, by Cronbach's Alpha Coefficient.

\section{Results}

Initially, descriptive analyses were performed by the participants' sex and then for the total sample considering SDQ and CSHQ scores. The results are described in Table 1.

\section{Table 1}

Descriptive statistics of SDQ and CSHQ scores

\begin{tabular}{|c|c|c|c|c|c|c|}
\hline Subscales & $\begin{array}{c}\text { Girls } \\
M(S D)\end{array}$ & $\begin{array}{c}\text { Boys } \\
M(S D)\end{array}$ & $\begin{array}{l}\text { Overall } \\
M(S D)\end{array}$ & Asymmetry & Kurtosis & $\begin{array}{l}\text { Min- } \\
\text { Max }\end{array}$ \\
\hline Emotional S. & $4.56(2.60)$ & $3.92(2.81)$ & $4.28(2.69)$ & 0.23 & -0.89 & $0-10$ \\
\hline Conduct P. & $1.97(1.86)$ & $2.64(1.89)$ & $2.29(1.89)$ & 0.54 & -0.57 & $0-7$ \\
\hline Hyperactivity & $4.12(2.67)$ & $4.78(2.51)$ & $4.43(2.59)$ & 0.31 & -0.73 & $0-10$ \\
\hline Relationship & $1.87(1.77)$ & $1.67(1.76)$ & $1.78(1.75)$ & 0.90 & -0.03 & $0-6$ \\
\hline Prosocial & $9.10(1.42)$ & $9.18(1.24)$ & $9.14(1.33)$ & -2.74 & 9.89 & $3-10$ \\
\hline Total SDQ & $12.40(6.04)$ & $12.75(5.73)$ & $12.56(5.85)$ & 0.44 & -0.16 & $1-27$ \\
\hline Resistance & $9.72(2.80)$ & $9.59(2.51)$ & $9.70(2.63)$ & 0.71 & -0.07 & $6-16$ \\
\hline Sleep onset & $1.50(0.74)$ & $1.38(0.71)$ & $1.43(0.72)$ & 1.36 & 0.34 & $1-3$ \\
\hline Duration & $4.26(1.57)$ & $4.10(1.57)$ & $4.18(1.54)$ & 1.09 & -0.11 & $3-8$ \\
\hline Anxiety & $6.75(2.34)$ & $6.14(2.39)$ & $6.48(2.35)$ & 0.69 & -0.61 & $4^{-12}$ \\
\hline Nocturnal A. & $4.14(1.29)$ & $3.76(0.86)$ & $3.98(1.11)$ & 1.37 & 2.34 & $3-8$ \\
\hline Parasomnias & $10.48(2.29)$ & $10.42(2.55)$ & $10.44(2.38)$ & 0.31 & -0.64 & $7-16$ \\
\hline Resp. Disorders & $4.24(1.37)$ & $4.39(1.85)$ & $4.32(1.60)$ & 1.20 & 0.63 & $3-9$ \\
\hline D. Sleepiness & $14.75(3.38)$ & $13.22(3.76)$ & $14.07(3.61)$ & 0.27 & -0.71 & $8-21$ \\
\hline Total CSHQ & $48.90(13.57)$ & $49.00(9.86)$ & $49.08(11.80)$ & -1.39 & 4.04 & $2-68$ \\
\hline
\end{tabular}

Note. Emotional S. - emotional symptoms; Conduct P. - conduct problems; Relationship relationship problems with peers; Prosocial - prosocial behaviors; Resistance - resistance to going to bed; Duration - sleep duration; Anxiety - sleep anxiety; Nocturnal A. - nocturnal awakenings; Resp. Disorders - respiratory disorders; D. Sleepiness - daytime sleepiness.

Subsequently, the Mann-Whitney Test was used to compare the scores of boys and girls. The results indicated that there was no statistically significant difference between both groups for emotional symptoms $[(U)=357.5 ; p=0.35]$, conduct problems $[(U)=328 ; p=0.14]$, hyperactivity $[(U)=367 ; p=0.22]$, relationship difficulties $[(U)=416 ; p=0.63]$, and prosocial 
behavior $[(U)=428.5 ; p=0.92]$. Likewise, no statistically significant differences were observed between boys and girls for sleep indexes, including: resistance to going to bed $[(U)=385 ; p=0.92]$, sleep onset $[(U)=395 ; p=0.46]$, sleep duration $[(U)=397.5 ; p=0.70]$, sleep anxiety $[(U)=328.5 ; p=0.20]$, nocturnal awakenings $[(U)=314.5 ; p=0.36]$, parasomnias $[(U)=388.5 ; p=0.77]$, sleep-disordered breathing $[(U)=391 ; p=0.80]$, and daytime sleepiness $[(U)=294 ; p=0.10]$. Therefore, there were no differences in the CSHQ and SDQ scores that could justify controlling this variable in further analyses.

Next, Spearman correlation analyses were carried out between the CSHQ scores and the SDQ scores, the latter answered by the parents/guardians, with the children's age (in months) and with the total ABEP score as an indicator of SES. The correlation analyses results are shown in Table 2.

Table 2

Spearman correlation between the CSHQ scores and the variables age, SDQ scores, and ABEP scores

\begin{tabular}{|c|c|c|c|c|c|c|c|c|}
\hline Sleep & Age & E. S. & C. P. & Hyp. & R. P. P. & Prosocial & SDQ & ABEP \\
\hline Bedtime & -0.04 & 0.01 & -0.17 & 0.15 & 0.24 & -0.01 & 0.12 & 0.11 \\
\hline Hours of sleep & $-0.40 * *$ & -0.10 & -0.19 & 0.00 & -0.14 & 0.04 & -0.10 & 0.10 \\
\hline Resistance & -0.07 & 0.23 & 0.07 & -0.03 & -0.09 & -0.08 & 0.09 & $-0.30 *$ \\
\hline Sleep onset & $0.27 *$ & 0.01 & 0.16 & $0.28 *$ & 0.11 & -0.21 & 0.23 & -0.04 \\
\hline Sleep duration & 0.01 & 0.25 & 0.18 & 0.19 & 0.17 & -0.10 & $0.31 *$ & -0.09 \\
\hline Sleep anxiety & -0.13 & 0.21 & -0.06 & -0.02 & -0.15 & 0.10 & 0.05 & -0.10 \\
\hline $\begin{array}{l}\text { Nocturnal } \\
\text { awakenings }\end{array}$ & 0.23 & 0.11 & 0.00 & -0.13 & -0.18 & 0.08 & -0.02 & -0.03 \\
\hline Parasomnia & -0.13 & $0.51 * *$ & 0.20 & $0.37 * *$ & 0.24 & -0.21 & $0.51 * *$ & -0.15 \\
\hline $\begin{array}{l}\text { Respirato- } \\
\text { ry Disorder }\end{array}$ & -0.06 & $0.41 * *$ & 0.04 & $0.38 * *$ & 0.18 & -0.21 & $0.44^{* *}$ & 0.00 \\
\hline $\begin{array}{l}\text { Daytime } \\
\text { sleepiness }\end{array}$ & 0.24 & 0.15 & 0.02 & 0.17 & 0.14 & -0.13 & 0.22 & 0.10 \\
\hline $\mathrm{CSHQ}$ & 0.08 & $0.41 * *$ & 0.15 & 0.25 & 0.20 & -0.09 & $0.45^{* *}$ & -0.06 \\
\hline
\end{tabular}

Note. E. S. - emotional symptoms; C. P. - conduct problems; Hyp - inattention and hyperactivity; R. P. P. - relationship problems with peers; Prosocial - prosocial behaviors; SDQ - total SDQ score of behavior problems; ABEP - socioeconomic status.

* correlation is significant at a $p \leq 0.05$ level.

** correlation is significant at a $p \leq 0.01$ level.

Italic: trend $(0.05<p \leq 0.07)$.

Regarding socioeconomic status, there was a negative, significant, low magnitude correlation between resistance to going to bed and the total score on the ABEP questionnaire, 
indicating that the lower the socioeconomic status, the greater the resistance to going to bed. With respect to age, a negative, significant, moderate correlation was found between hours of sleep and age in months, indicating that the younger the child, the more hours of sleep. An increase in age, in turn, is related to a decrease in the amount of sleep. A positive, significant, low-magnitude correlation was also found between sleep onset and age, i.e., the older the age, the later the sleep onset. Also, in relation to age, a trend towards a positive correlation with daytime sleepiness was observed.

A positive, significant, moderate correlation was observed between the total CSHQ score and the total SDQ score. In the analysis of the specific domains of the CSHQ, it was noted that sleep duration and the presence of parasomnias and respiratory disorders correlated positively, significantly, and with a moderate magnitude with the total SDQ scores.

Concerning the specific domains of SDQ, no significant correlations were observed between the different aspects of sleep and conduct problems, relationships with peers, and prosocial behavior. In the case of problems in the relationship with peers, there was a low-correlation trend with parasomnias. On the other hand, a positive, significant, low-magnitude correlation was observed between symptoms of inattention/hyperactivity with sleep onset, parasomnias, and sleep-disordered breathing. It is noted that longer time for sleep onset and the presence of parasomnias or respiratory disorders are related to a higher frequency of inattention symptoms/hyperactivity. These scores also tended to have a low correlation with the total CSHQ scores.

A positive, significant, moderate correlation was found between emotional symptoms and parasomnias together with sleep-disordered breathing. So, it is observed that the more symptoms of parasomnias and sleep-disordered breathing the child presents, the more emotional difficulties are reported by caregivers.

Regression analysis allowed the identification of a model with a Determination Coefficient of 0.232 . Thus, it was observed that the sleep characteristics as measured by the CSHQ explain $23 \%$ of the score variance observed in behavioral problems that are indicators of health in children between 4 and 10 years of age. Table 3 displays the model resulting from the regression.

\section{Table 3}

Regression Model Summary

\begin{tabular}{ccccccc}
\hline Model & $\mathbf{R}$ & $\mathbf{R}^{2}$ & adjusted $\mathbf{R}^{2}$ & Estimate SE & $\mathbf{F}$ & $\boldsymbol{p}$ \\
\hline 1 & 0.482 & 0.232 & 0.219 & 5.22 & 17.263 & $<0.001$ \\
\hline
\end{tabular}


Finally, this study is the first one conducted with the Brazilian Portuguese version of the CSHQ (CSHQ-BR), which was previously translated and adapted by Gios (2020). Although previous studies with the European Portuguese version, i.e., PT-CSHQ (Silva et al., 2014), were also conducted in Brazil (Loekmanwidjaja et al., 2018; Urrutia-Pereira et al., 2017), in this study, we chose to use the cross-culturally adapted version for Brazil, in view of the need to use instruments properly adapted to the context in which it is administered (Borsa et al., 2012). An analysis of the instrument's internal consistency was conducted for the present sample, which indicated a Cronbach's Alpha Coefficient of 0.75 . This value is considered adequate, indicating a good item-total correlation of the items that make up the instrument.

\section{Discussion}

Considering previous studies with different populations around the world, which report the association between sleep and mental health in childhood (Wu et al., 2016; Liu et al., 2014; Wang et al., 2020) and the scarcity of available questionnaires in a national context for the assessment of sleep characteristics, this study aimed to investigate the relationship between characteristics serving as indicators of sleep problems and a screening measure for internalizing and externalizing symptoms used as a triage instrument for mental health in children. Also, the screening instruments used are widely employed in several national and international studies, which contributes to the first validity evidence and accuracy findings to the Brazilian version of the CSHQ.

According to a classification previously established for SDQ scores (Goodman, 1997), on average, children were considered borderline for emotional symptoms, i.e., having more symptoms as reported by caregivers than the expected for this age group. On the other hand, the scores were within the normal range for conduct problems, hyperactivity, difficulties with peers, and prosocial behavior. In the case of CSHQ, there is still no established cutoff point for the Brazilian population. But when comparing the data obtained in this sample with the 41-point criterion used in international studies (Owens, 2000), an average of eight points above the expected was observed, albeit with a standard deviation of 11 points, the lower limit of which would be compatible with the cutoff score used. In this sense, future studies with representative samples of the Brazilian population should establish a cutoff point that would be more compatible with the sleep characteristics found in the country.

Initially, the results were compared between boys and girls to investigate possible differences in scores that could impact the relationship between mental health indicators and sleep problems. The results showed no statistically significant differences between the scores of boys and girls either in the total score or in the subscales of the CSHQ and SDQ, therefore corroborating a previous study conducted by Lianqi et al. (2004) with Chinese children. Correlation analyses with the CSHQ-BR were then performed considering the sample as a whole. 
It is known that sleep problems can have different characteristics (Nelson et al., 2018; Nunes \& Bruni, 2015), in the same manner as there are different indicators of mental health problems (Goodman, 1997). For this reason, we chose to correlate the questionnaires' subscales beyond their total scores.

In this study, a positive relationship was found between the total CSHQ score (indicating greater sleep difficulties) and emotional problems in childhood, in addition to a specific association between parasomnias together with sleep-disordered breathing and emotional difficulties. The results show that an increase in characteristics indicating sleep problems is associated with higher indicators of mental health impairment, as reported by family members. Emotional symptoms are known to be cardinal in many mood disorders. Still, a recent study discusses specific and relatively common sleep difficulties, such as difficulty sleeping alone and increased sleep onset latency as predictors of depression and severity of anxiety symptoms over time (Whalen et al., 2016). Some studies report that emotional symptoms and sleep disorders in children may be related to the motherhood type, i.e., the more present the mother is when raising her child, the fewer the sleep disorders and, consequently, fewer emotional problems. Preschool children experiencing insecurity and ambivalence in their attachment relationships may experience impaired sleep quality (Schlarb et al., 2016). In this sense, future studies could investigate whether the relationship between sleep problems and emotional symptoms is mediated or moderated by characteristics pertaining to the child's attachment to their caregiver.

It was observed that the later the sleep onset, the higher the score on the SDQ hyperactivity subscale. Also, parasomnias and sleep-disordered breathing are also positively associated with hyperactivity. This indicates that these sleep-specific variables are related to an increase in general indicators of mental health problems. These results replicated those obtained in previous studies, indicating a universal association between sleep disorders and behavioral problems in children from different countries (Li et al., 2008; Nelson et al., 2018), specifically an association with externalizing problems, such as hyperactivity (Wang et al., 2020), for instance. These authors found lower correlations between symptoms of hyperactivity and parasomnias, respiratory disorders, and sleep onset when compared to the correlations observed in this study. Such variations in correlation magnitude may be due to sample size, age, and cultural aspects that influence both the children's sleep and mental health. It is also noteworthy that children aged 7-8 years old with ADHD, i.e., having a consistent functional impairment resulting from symptoms of hyperactivity, sleep fewer hours when compared to those who do not have that disorder (Paavonen et al., 2009).

Regarding age, the findings of this study also indicated that the younger the child, the more hours of sleep are reported by their caregivers. It was noted that the older the child, the longer the sleep onset time, which thus decreases the child's number of sleep hours. Among 
the factors that may justify a late sleep onset there is the use of electronic devices, watching television before sleeping, which lead to greater exposure to screen light, thereby impairing sleep hygiene. One hypothesis would be that, with increasing age, caregivers have less control over the nighttime use of these devices. It is known that the current lifestyle leads to social changes, having a negative impact on sleep patterns, such as nocturnal awakenings, fewer hours of sleep, and, in some cases, insomnia (Hoge et al., 2017). There was also a trend towards a correlation between age and daytime sleepiness, a finding that has also been observed by other authors (Liu et al., 2019). This relationship can also be explained in terms of the fewer hours of sleep as age increases.

In relation to SES, there was a greater correlation with resistance to going to bed, indicating that the lower the SES, the greater the resistance. The relationship between lower SES and sleep-related problems has also been discussed, since shared rooms, family stress, and greater difficulty in establishing sleep limits and routines could lead to such losses (Crabtree et al., 2005; Li et al., 2008).

Finally, in this present study, $23 \%$ of the variance in internalizing and externalizing mental health indicators (total SDQ score) was significantly explained by sleep characteristics, thus corroborating data published across a vast literature in the field reporting changes in the sleep pattern as a risk factor for and as a diagnostic criterion in mental health (Nelson et al., 2018; Wang et al., 2020).

Nevertheless, this work has some limitations. Sleep characterization was measured by using the shortened version of the CSHQ-BR, and that is a measure reported by caregivers. The combined use of objective sleep measures, such as actigraphy and polysomnography, would better detail sleep characteristics in this population. It is important that additional studies assess children's sleep and behavior through other informants, which would allow for a better understanding of the child's functioning in different contexts. The sample of this study was restricted to 60 children from one single public school in the city of Sao Paulo, Brazil. It is hoped that this work can further stimulate the conduction of national research on the subject, with larger samples that contemplates Brazil's population heterogeneity.

On the other hand, an important contribution of this study stems from the findings, providing the first evidence of both validity and accuracy of the CSHQ adapted to Brazilian Portuguese. The use of simple screening instruments in a school setting could help identify children at risk who should be referred to mental health services, which should prevent symptoms having an onset in childhood from becoming chronic. Understanding sleep pattern as a possible risk factor associated with psychiatric disorders signals the need for a detailed, more in-depth clinical investigation into this matter, thereby contributing to early diagnosis and intervention and consequently modifying the prognosis and the disease course. 


\section{References}

Associação Brasileira de Empresas de Pesquisa (ABEP). (2019). Critério de Classificação Econômica Brasil. http://www.abep.org/criterio-brasil

Barbisan, B., \& Bueno, C. (2019). Sono normal na criança: A evolução do sono nas diversas idades. In B. Barbisan., C. Santos \& E. Motta. (Orgs.), Medicina do Sono (pp. 3-24). Atheneu.

Borsa, J. C., Damasio, B. F., \& Bandeira, D. R. (2012). Cross-cultural adaptation and validation of psychological instruments: Some considerations. Paidéia, 22(53), 423-432. https://doi.org/10.1590/ S0103-863X2012000300014

Crabtree, V., Korhonen, J., Montgomery-Downs, H., Jones, V., O'Brien, L., \& Gozal, D. (2005). Cultural influences on the bedtime behaviors of young children. Sleep Medicine, 6(4), 319-324. https://doi. org/10.1016/j.sleep.2005.02.001

Cruz, L., Vizcaino, V. M., Bueno, C. A., Palencia, N. A., Lopez, M. S., \& Pacheco, B. N. (2016). Reability and validity of the Spanish version of the Children's Sleep Habits Questionnaire in school-age children. Child: Care, Health and Development, 42(6), 675-682. https://doi.org/10.1111/cch.12357

Damiani, J., Sweet, B., \& Sohoni, P. (2014). Melatonin: An option for managing sleep disorders in children with autism spectrum disorder. American Journal of Health-System Pharmacy, 71(2), 95-101. https://doi.org/10.2146/ajhp130215

Gios, T. S. (2020). Tradução e Adaptação Cultural para a Língua Portuguesa do Brasil do Questionário de Hábitos de Sono em Crianças (CSHQ-BR). [Unpublished Master's Dissertation]. Faculdade de Ciências Médicas da Santa Casa de São Paulo.

Goodman, R. (1997). The Strengths and Difficulties Questionnaire: A research note. Journal of Child Psychology and Psychiatry, 38(5), 581-586. https://doi.org/10.1111/j.1469-7610.1997.tb01545.x

Hoge, E., Bickham, D., \& Cantor, J. (2017). Digital media, anxiety, and depression in children. Pediatrics, 140(2), S76-S80. https://doi.org/10.1542/peds.2016-1758G

Li, S., Jin, X., Yan, C., Wu, S., Jiang, F., \& Shen, X. (2008). Bed- and room-sharing in Chinese school-aged children: Prevalence and association with sleep behaviors. Sleep medicine, 9(5), 555-563. https:// doi.org/10.1016/j.sleep.2007.07.008

Lianqi, L., Chaojuan M., Ruzhan, W., Chunni, G., \& Xianchen, L. (2004). Sleep problems and related factors of elementary school students. Chinese Mental Health Journal, 18(9), 52-69. http://en.cnki. com.cn/Article_en/CJFDTotal-ZKLS201207026.htm

Liu, X., Liu, L., \& Wang, R. (2003). Bed sharing sleep habits, and sleep problems among Chinese schoolaged children. Sleep, 26(7), 839-844. https://doi.org/10.1093/sleep/26.7.839

Liu, Z., Wang, G., Tang, H., Wen, F., \& Li, N. (2014). Reliability and validity of the children's sleep habits questionnaire in preschool-aged Chinese children. Sleep and Biological Rhythms, 12(3), 187-193. https://doi.org/10.1111/sbr.2014.12.issue-3

Liu, Y., Zhang, J., Li, S. X., Chan, N. Y., Yu, M. W. M., Lam, S. P., \& Wing, Y. K. (2019). Excessive daytime sleepiness among children and adolescents: Prevalence, correlates, and pubertal effects. Sleep Medicine, 53, 1-8. https://doi.org/10.1016/j.sleep.2018.08.028

Loekmanwidjaja, J., Carneiro, A. C. F., Nishinaka, M. L. T., Munhoes, D. A., Benezoli, G., Wandalsen, G. F., \& Solé, D. (2018). Distúrbios do sono em crianças com rinite alérgica persistente moderada-grave. Brazilian Journal of Otorhinolaryngology, 84(2), 178-184. https://doi.org/10.1016/j.bjorl.2017.01.008 
Miano, S., Parisi, P., \& Villa, M.P. (2012). The sleep phenotypes of attention deficit hyperactivity disorder: The role of arousal during sleep and implications for treatment. Med Hypotheses, 79(2), 147153. https://doi.org/10.1016/j.mehy.2012.04.020

Moore, M., Evans, V., Hanvey, G., \& Johnson, C. (2017). Assesment of sleep in children with autism spectrum disorder. Children, 4(8), 72. https://doi.org/10.3390/children4080072

Nelson, T. D., Kidwell, K. M., Hankey, M., Nelson, J. M., \& Espy, K. A. (2018). Preschool executive control and sleep problems in early adolescence. Behavioral Sleep Medicine, 16(5), 494-503. https://doi.or g/10.1080/15402002.2016.1228650

Neves, G., Macedo P., \& Gomes M. (2017). Transtornos do Sono: Atualização. Revista Brasileira de Neurologia, 53(3), 19-30. https://pesquisa.bvsalud.org/portal/resource/pt/biblio-876873

Nunes, M. L., \& Bruni, O. (2015). Insomnia in childhood and adolescence: Clinical aspects, diagnosis and therapeutic approach. Jornal de Pediatria, 91(6), 26-35. https://doi.org/10.1016/j.jped.2015.08.006

Owens, J. A., Spirito, A., \& McGuinn, M. (2000). The Children's Sleep Habits Questionnaire (CSHQ): Psychometric properties of a survey instrument for school-aged children. Sleep, 15;23(8), 1043-1051. https://doi.org/10.1037/t33022-000

Owens, J. A., \& Mindell, J. A. (2011). Pediatric Insomnia. Pediatric Clinics of North America, 58(3), 555-569. https://doi.org/10.1016/j.pcl.2011.03.011

Paavonen, E. J., Räikkönen, K., Lahti, J., Komsi, N., Heinonen, K., Pesonen, A. K., Jarvenpaa, A., Strandberg, T., Kajantie, E., \& Porkka-Heiskanen, T. (2009). Short sleep duration and behavioral symptoms of attention-deficit/hyperactivity disorder in healthy 7-to 8-year-old children. Pediatrics, 123(5), e857-e864. https://doi.org/10.1542/peds.2008-2164

Saur, A. M., \& Loureiro, S. R. (2012). Qualidades psicométricas do Questionário de Capacidades e Dificuldades: Revisão da literatura. Estudos de Psicologia (Campinas), 29(4), 619-629. https://doi. org/10.1590/S0103-166X2012000400016

Schlarb, A. A., Jaeger, S., Schneider, S., In-Albon, T., \& Hautzinger, M. (2016). Sleep problems and separation anxiety in preschool-aged children: A path analysis. Journal of Child and Family Studies, 25(3), 902-910. https://doi.org/10.1007/s10826-015-0262-z

Schlarb, A. A., Schwerdtle, B., \& Hautzinger, M. (2010). Validation and psychometric properties of the German version of the Children's Sleep Habits Questionnaire. Somnologie. Schiafforschung und Schlafmedizin, 14, 260-266. https://doi.org/10.1007/s11818-010-0495-4

Silva, T. B., Osório, F. L., \& Loureiro, S. R. (2015). SDQ: Discriminative validity and diagnostic potential. Frontiers in Psychology, 6, 811. https://doi.org/10.3389/fpsyg.2015.00811

Silva, F. G., Silva, C. R., Braga, L. B., \& Neto, A. S. (2014). Portuguese Children's Sleep Habits Questionnaire: Validation and cross-cultural comparison. Jornal de Pediatria, 9o(1), 78-84. http://dx.doi. org/10.1016/j.jped.2013.06.009

Tso, W., Rao, N., Jiang, F., Li, A. M., Lee, S. L., Li, S., Ip, P., \& Ho, F. K. (2016). Sleep duration and school readiness of Chinese preschool children. The Journal of Pediatrics, 169(11), 266-271. https://doi. org/10.1016/j.jpeds.2015.10.064

Tzchishinsky, O., Lufi, D., \& Shochat, T. (2008). Reliability of the Children's Sleep Habits Questionnaire Hebrew Translation and Cross Cultural Comparison of the Psychometric Properties. Sleep Diagnosis and Therapy, 3(3). https://sleepdt.com/reliability-of-the-childrens-sleep-habits- 
questionnaire-hebrew-translation-and-cross-cultural-comparison-of-the-psychometric-properties/

Urrutia-Pereira, M., Solé, D., Neto, H. C., Acosta, V., Cepeda, A. M., Álvarez-Castelló, M., Almendarez, J., Lozano-Saenz, J. C., Sisul-Alvariza, N. A., Rosario, A. J., Castillo, M., Valentin-Rostan, H., Badellino, R. L., Castro-Almarales, M., González-León, C., Sanchez-Silot, M. M., Avalos, C., Fernandez, F., Berroa, M. M., De la Cruz, R. O. S., \& Sarni, R. S. (2017). Sleep disorders in Latin-American children with asthma and/or allergic rhinitis and normal controls. Allergologia et immunopathologia, 45(2), 145-151. https://doi.org/10.1016/j.aller.2016.05.005

Vaughn, B. E., Elmorestaton, L., Shin, N., \& Elsheikh, M. (2015). Sleep as a support for social competence, peer relations, and cognitive functioning in preschool children. Behavioral Sleep Medicine, 13(2), 92-106. https://doi.org/10.1080/15402002.2013.845778

Waumans, R. C., Terwee, C. B., Van den Berg, G., Knol, D. L., Van Litsenburg, R. R. L., \& Gemke, R. J. (2010). Sleep and Sleep Disturbance in Children: Reliability and Validity of the Dutch Version of the Child Sleep Habits Questionnaire. Sleep, 33(6), 841-845. https://doi.org/10.1093/sleep/33.6.841

Whalen, D. J., Gilbert, K. E., Barch, D. M., Luby, J. L., \& Belden, A. C. (2016). Variation in common preschool sleep problems as an early predictor for depression and anxiety symptom severity across time. Journal of Child Psychology \& Psychiatry, 58(2), 151-159. https://doi.org/10.1111/jcpp.12639

Wang, G., Takahashi, M., Wu, R., Liu, Z., Adachi, M., Saito, M., Nakamura, K., \& Jiang, F. (2020). Association between Sleep Disturbances and Emotional/Behavioral Problems in Chinese and Japanese Preschoolers. Behavioral Sleep Medicine, 18(3), 420-431. https://doi.org/10.1080/15402002. 2019.1605995

Wu, X., Tao, S., Rutayisire, E., Chen, Y., Huang, K., \& Tao, F. (2016). The relationship between screen time, nighttime sleep duration, and behavioural problems in preschool children in China. European Child \& Adolescent Psychiatry, 26(5), 541-548. https://doi.org/10.1007/s00787-016-0912-8

Xie, Z., Chen, F., Li, W., Geng, X., Li, C., Meng, X., Feng, Y., Liu, W., \& Yu, F. (2017). A review of sleep disorders and melatonin. Neurological Research, 39(6), 559-565. https://doi.org/10.1080/0161641

2.2017 .1315864

Editorial board

Editor-in-chief

Cristiane Silvestre de Paula

\section{Associated editors}

Alessandra Gotuzo Seabra

Ana Alexandra Caldas Osório

Luiz Renato Rodrigues Carreiro

Maria Cristina Triguero

Veloz Teixeira

Section editors

"Psychological Evaluation"

Alexandre Luiz de Oliveira Serpa

André Luiz de Carvalho Braule Pinto

Luiz Renato Rodrigues Carreiro

Vera Lúcia Esteves Mateus

"Psychology and Education"

Alessandra Gotuzo Seabra

Carlo Schmidt

Regina Basso Zanon

\section{"Social Psychology and Population's Health" \\ Enzo Banti Bissoli \\ Marina Xavier Carpena}

\section{"Clinical Psychology"}

Carolina Andrea Ziebold Jorquera

Julia Garcia Durand

Natalia Becker

\section{Human Development" \\ Maria Cristina Triguero Veloz Teixeira \\ Rosane Lowenthal}

\section{Technical support}

Maria Fernanda Liuti Bento da Silva Camila Fragoso Ribeiro
Editorial production

Publishing coordination

Ana Claudia de Mauro

Editorial interns

Júlia Lins Reis

Pietro Menezes

Élcio Carvalho

Language editor

Daniel Leão

Layout designer

Acqua 


\title{
Appendix 1. CSHQ-BR (abbreviated version)
}

\author{
Questionário de Hábitos de Sono em Crianças (CSHQ-BR) \\ (versão abreviada/ pré-escolar e escolar)
}

\section{Pontuação Total}

Seguem abaixo afirmações sobre hábitos e possíveis dificuldades de sono das crianças. Pense na última semana do seu filho(a) para responder às questões. Se a última semana foi atípica por algum motivo específico, escolha uma semana comum mais recente. Responda USUALMENTE se ocorreu 5 ou mais vezes na semana; responda ÀS VEZES se ocorreu entre 2 e 4 vezes na semana; responda RARAMENTE se ocorreu uma vez na semana ou nunca.

Observação: substituir a palavra "cama" por "rede", se necessário.

\section{Hora de dormir}

Escreva a hora que a criança vai dormir:

USUALMENTE ÀS VEZES RARAMENTE

1

1) A criança vai para a cama sempre na mesma hora

$(5-7)$

$(2-4)$

$(0-1)$

2) A criança adormece dentro de 20 minutos após

ir para a cama

3) A criança adormece sozinha na sua própria cama
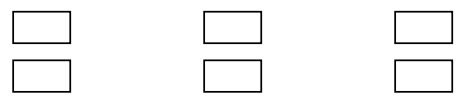

4) A criança adormece na cama dos pais ou dos irmãos
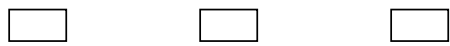

5) A criança precisa da presença dos pais no quarto para adormecer

6) A criança luta contra o sono na hora de dormir (chora, se recusa a ficar na cama...)

7) A criança tem medo de dormir no escuro

8) A criança tem medo de dormir sozinha
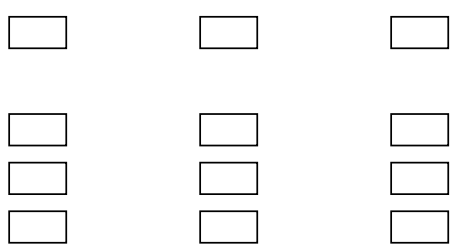

\section{Hábitos de sono}

Quantidade habitual de sono por dia: horas e minutos

(levar em conta as horas de sono da noite e sonecas) 
10) A criança dorme a quantidade certa

11) A criança dorme o mesmo tempo de sono todos os dias

12) A criança molha a cama à noite

13) A criança fala durante o sono

14) A criança fica inquieta e se move bastante durante o sono

15) A criança caminha enquanto dorme

16) A criança vai para a cama de outra pessoa durante a noite (pais, irmão, irmã...)

17) A criança range os dentes durante o sono (seu dentista pode ter mencionado isso)

18) A criança ronca alto

19) A criança parece parar de respirar durante o sono

20) A criança bufa e/ou suspira durante o sono
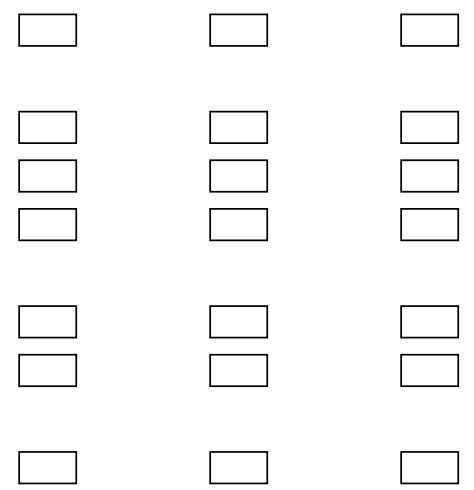

21) A criança tem dificuldade para dormir longe de casa (quando visita parentes, férias...)
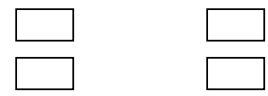

22) A criança acorda durante a noite gritando, suando e inconsolável

23) A criança acorda agitada após pesadelo

\section{Acordar durante a noite}

3
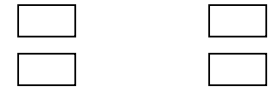

24) A criança acorda uma vez durante a noite USUALMENTE ÀS VEZES RARAMENTE

25) A criança acorda mais de uma vez durante a noite

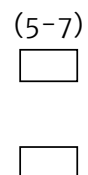

$(2-4)$

$(0-1)$

Escreva quantos minutos duram os despertares noturnos:

\section{Acordar pela manhã}

Escreva a hora que a criança acorda pela manhã:

3

2

1

USUALMENTE ÀS VEZES

RARAMENTE

26) A criança acorda sozinha

$\begin{array}{lll}(5-7) & (2-4) & (0-1) \\ \square & \square & \square\end{array}$


27) A criança acorda mal-humorada

28) A criança é acordada por um adulto ou irmão
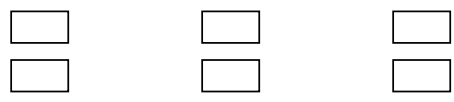

29) A criança tem dificuldade em levantar da cama pela manhã
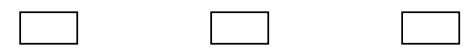

30) A criança leva bastante tempo para ficar alerta pela manhã
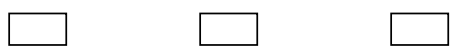

\section{Sonolência durante o dia}

31) A criança parece cansada

A criança apresentou muito sono, adormeceu ou ficou sem sono durante as seguintes atividades:

1

Sem sono

32) Assistindo TV

33) Andando de carro

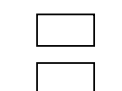

2

3

Não
Muito sono

Adormeceu

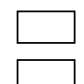

Aplicável 